\title{
THE PHYSIOLOGY OF STIMULATION- PRODUCED ANALGESIA
}

\author{
David Bowsher,
}

\author{
Pain Research Institute, Liverpool Uni- \\ versity Department of Neurological Sci- \\ ences
}

\section{NERVE FIBRES IN THE PERIPHERY (Fig. 1)}

There are essentially three types of nerve fibre bringing messages from the periphery (Fig. 1 ). The largest, and most rapidly-conducting fibres, known as $A \beta$, convey messages generated by low-intensity mechanical stimuli, such as touch, stroking, rubbing, or pressure. These fibres will carry many hundreds of messages per second. These large $A \beta$ fibres have a myelin sheath. There are also smaller fibres with a myelin sheath, known as A $\delta$, which carry messages generated by high-intensity mechanical stimuli, such as pinprick. These fibres carry very many fewer massages per second. The natural reaction to stimulation of A $\delta$ fibres is to withdraw. The smallest nerve fibres, which fave no myelin sheath (unmyelinated or $\mathrm{C}$ fibres) mostly carry messages brought about by tissue damage; when these massages become conscious, homan beings call them "pain". Messages in $\mathrm{C}$ fibres travel very slowly, and the fibres can only carry a few messages per second. The natural reaction to $\mathrm{C}$ fibre stimulation is for muscles to contract and remain contracted, so that the affected part, or even the whole organism, remains still - this gives the best chance of natural healing, while the withdrawal brought about by A $\delta$ fibre activation by sharp objects protects the organism from possibility of damage.

For short, we will refer to large rapidly-conducting A $\beta$ fibres as "touch fibres", small myelinated A $\delta$ fibres as "pinprick fibres", and unmyelinated C fibres as "pain fibres" .

Two types of cutaneous stimulation have been known from time immemorial to be effective in relieving pain. The first is the instinctive action of "rubbing a pain better", and the second is acupuncture. Rubbing is done rapidly and lightly, so in physical terms constitutes high-frequency low-intensity stimulation. Acupuncture is performed with a needle, which is rotated fairly slowly (about 3 or 3 times a second), and so constitutes low-frequency highintensity stimulation.

Fairly obviously, "rubbing better" must stimulate touch fibres in the skin with low thresholds. Since sustained pressure is not effective in producing pain relief, the effective touch fibres must be a special must be a special category of nerve excited only by moving (transient) stimuli and not by sustained pressure. Therapeutically, pain relief by activation of these special touch fibres is obtained by transcutaneous electrical nerve stimulation (TENS) (Wall \& Sweet, 1967). It can also be obtained by the application of vibratory stimuli (Lunde- 
berg, 1983), Which presumably activate movement-sensitive nerve endings in muscle.

Acupuncture presents a more difficult problem, because it was first necessary to demonstrate that nerves are involved at all. Happily experiments which showed that when a nerve is blocked with local anaesthetic, acupuncture is ineffective in the territory supplied by that nerve, demonstrate that the acupuncture effect is conducted along nerves (Chiang et al., 1973). Then it was known that acupuncture is only effective at certain points on body surface. In fact, comparison with an anatomical atlas shows that many acupuncture points correspond with the points at which small nerve bundles penetrate the fascia; Chan (1984) cites two Chinese studies which showed that 309 acupuncture points are situated on or very close to nerves, while a further 286 are on or very close to major blood vessels surrounded by small nerve bundles. That sympathetic nerves may be involved was first demonstrated by Goulden (1921) who showed that acupuncture points along the sciatic nerve and its branches had a lower resistance than the surrounding skin. Yoshio (1967) has shown that Ryodoraku points have are similar. Many acupuncture points are of course deep to the skin : Melzack et al (1977) have shown that they correlate closely with Travell's "trigger points", while Liu et al. (1977) have shown that others correspond with the motor points of muscles, where the nerves enter or leave them. The kind of nerve involved is obviously the A $\delta$ or pinprick fibre.

\section{SPINAL CORD MECHANISMS (Fig. 2)}

The next question to be asked, obviously, is where and how do these two types of nerve fibre (large and small) end in the spinal cord? Fortunately recent advances in anatomy and physiology can tell us a qreat deal about these questions.

All nerve fibres from the skin enter the spinal cord in the dorsal root and pass towards the brain without relay, to end in the dorsal column (qracile and cuneate) nuclei at the junction of spinal cord and brain. However, on entry to the spinal cord, these fibres give off a branch which penetrates the grey matter of the spinal cord. Some arborisations of this branch make contact in the superficial part of the dorsal horn, probably through an interneurone which releases the inhibitory substance gamma-amino-butyric acid (GABA) (Todd and McKenzie, 1989), onto the terminals of small incoming "pain" fibres (see Brown et al., 1978). Such an anatomical arrangement would explain the GABA-mediated inhibition observed by Duggan and Foong (1985) following dorsal column stimulation (see below), which drives the segmental branches responsible for TENS backwards. It is of course well-known that these systems respond to high frequencies of stimulation. We thus have a circuit capable of explaining, at at segmental level, the pain-relieving effectsof TENS and vibration. Note that this circuit does not involve any nerve terminals which release enkephalin or other naturally-occurring morphine-like substances, and therefore the analgesia produced by segmental TENS is not reversed or antagonised by naloxone (Sjölund and Eriksson, 1979), which is a drag which blocks the effects of morphine and its naturally-occurring analogues. Naloxone is in fact a very useful tool in human pain research, because it can reveal which mechanisms of pain relief are due to morphine-like substances and which not.

pain relief by acupuncture, on the other hand, is reversed or blocked by naloxone (Mayer et al., 1977 ; Sjölund \& Eriksson, 1979; Cheng \& Pomeranz, 1980), and we must thus look for an entirely different explanation of its effects. The small myelinated skin fibres which carry the 
pinprick messages to the spinal cord make their principal intraspinal contact with the large cells in the most superficial part of the spinal grey matter (Kumazawa and perl, 1978) ; from here, messages about pinprick are carried direct to the brain by long fibres in the anterior and lateral part of the white matter of the spinal cord (anterolateral funiculus, ALF in figs. 2 and 4 ). In the region of these large cells, there are other very small cells, called "stalked cells" (cat : Bennett et al., 1982 ; man : Abdel-Maguid and Bowsher, 1984) which suppress activity in slightly deeper cells (called " $S G$ " in fig. 2 ) which receive pain fibres by releasing onto them the inhibitory transmitter enkephalin, which is a naturally-occurring morphine-like substance (Ruda et al. 1984). Branches of the "pinprick" fibres also make contact with these stalked cells, called "Enk" in fig. 2 (Gobel et al., 1980). The SG cells, which normally receive messages from pain fibres, send their messages through other cells deeper in the spinal cord grey matter (called $S R$ in fig. 2) which eventually project up to the brain in the anterolateral funiculus ( $A L F$ in figs. 2 and 4 ). It has also been shown that stalked cells do not react to frequencies of stimulation above about 3 per second (Bowsher et al., 1968; Harper and Lawson, 1985), which is, of course, the maximal frequency at which acupuncture is performed. These mechanisms are quite adequate to explain the segmental mechanisms of acupuncture analgesia.

At segmental level, both high-frequency low-intensity pain-relieving stimulation (TENS) and low-frequency high-intensity pain-relieving stimulation (acupuncture) are adequately explained by the gate control theory of Melzack and Wall (1965) (Fig. 3). TENS acts by closing the gate from outside-the large touch/vibration fibres are seen as pulling the gate to from the outside, and so preventing the entry of messages in pain fibres. Segmental acupuncture through blocking the messages in pain fibres as they pass through the gate, so preventing them going beyond the gate.

However, both mechanisms of stimulation-produced pain relief also act at higher levels of the central nervous system. In order to study this, we must first examine the relevant ascending and descending pathways.

\section{ASCENDING PATHWAYS (Fig. 4)}

1. Touch fibres from the skin, carrying the kind of information generated by TENS, pass up the dorsal columns of the spinal cord to end in gracile and cuneate muclei (not shown in fig. 4 ). From the dorsal column (gracile and cuneate) nuclei, further nerve fibres cross over and travel up the brainstem to reach the thalamus (VP in fig. 4), whence messages are relayed to the cerebral cortex (fig. 4, PCG) and so to consciouseness. However, the medial lemniscus gives off a number of branches on the way, nost notably in the midbrain. The connection in which we are most interested in the present context is to the anterior pretectal nucleus (Björkeland and Boivie, 1984 ; Rees and Roberts, 1989 a) (not shown in Fig. 4). This nucleus projects to the periaqueductal grey matter (PAG in Fig. 4)) (Rees and Roberts 1989 b), and thence activates the descending inhibitory system (Fig. 5 ) which is discussed below.

2. Information generated by pinprick passes up the anterolateral funiculus (ALF, fig. 4) on the side opposite to that on which it enters the cord (Kuru 1949). The medial brainstem reticular formation receives the majority of the ascending fibres (Bowsher 1957). It is now known that these fibres originate from the deep grey matter of the spinal cord (SR in fig. 2) 
(Kevetter et al., 1982), having been activated through the substattia gelatinosa (SG in fig. 2) by unmyelinated "pain" fibres which terminate principally in the substantia gelatinosa (Sugiura and perl, 1986), though some spinoreticular fibres also arise from the neck of the dorsal horn. A smaller component of the ascending anterolateral funiculus reaches the ventrobasal thalamus (VP in fig. 4), in company with the medial lemniscus (see above) carrying touch impulses (Bowsher 1957). This component arises principally from the tip and neck of the dorsal horn (ST in fig. 2) (Willis et al., 1979), and gives off branchess to the periaqueductal grey matter (PAG) of the midbrain in its course (Fig. 4) (Botsher 1957). Mantyh (1982) showed that this projection comes from the most superficial part of the spinal grey matter; Pechura and Liu (1986) suggested that some spino-PAG neurones also reside in the neck of the dorsal horn. It is in these areas that fine myelinated "pinprick" fibres terminate (Heimer and Wall, 1968; Rethelyi et al., 1982). Thus there exist pathways whereby pinprick information is conveyed to the PAG.

\section{DESCENDING PATHWAYS (Fig. 5)}

It was in 1964 that Tsou and Jang demonstrated that the PAG is the most effective spot in the whole central nervous system for the abolition of pain by microinjection. As the PAG was known not to send messages upwards to the cerebral cortex and so to consciousness, this amazing finding was conveniently ignored by Western researchers. However, in 1969 Reynolds, in the U.S.A., showed that painless surgery could by carried out on the rat during electrical stimulation of the PAG, and this led to intensive research on possible mechanisms in western laboratories. Investigations by Mayer and Liebeskind (1974) showed that a descending inhibitory pathway passing down from the caudoventral part of the PAG to the spinal cord was responsible for the inhibition of ascending neurones carrying messages generated by painful stimuli. It is precisely the caudoventral PAG which receives the ascending spinothalamic branchess referred to in the previous section (Mantyh, 1982). Furthermore, there is evidence that there is a somtatotopic (body) organisation within this part of the PAG (Soper and Melzack, 1982) ; this might explain why heterosegmental acupuncture cannot be obtained from any acupuncture point, must be applied to particular points, not necessarily within the dermatome where pain relief is to be obtained. This is perhaps best illustrated by the bodily representation in ear acupuncture points.

The pathway descending from the PAG, whose transmitter substance is probably neurotensin (Beitz, 1982), relays in the nucleus raphe magnus (NRM) of the medulla oblongata (Fig. 5 ). From the NRM, fibres whose transmitter substance is mainly serotonin ( 5 -hydroxytryptamine, 5-HT in Fig. 5) descend in the dorsolateral funiculus of the spinal cord to terminate directly on the stalked enkephalin-containing interneurones in the spinal dorsal horn (Glazer and Basbaum, 1984) which were discussed above. There are also serotoncontaining nerve terminals ending freely in the superficial part of the spinal cord grey matter (Maxwell et al. 1983; Leranth et al., 1984 ; Hammond et al, 1985). This could explain the "hormonal" or generalised type of acupuncture effect, as opposed to the point-to-point or neural type.

Finally, it will be recalled that the PAG receives fibres containg the naturally-occurring morphine-like substance $\beta$-endorphin (Bloom et al., 1978) ; these fibres descend from the 
hypothalamus (Mantyh, 1982), a primitive but essential part of the forebrain concerened not only with regulation of bodily functions but also with emotion. In man, the hypothalamus is under control of the prefrontal cortex in man. It is because the pathway from hypothalamus to PAG is endorphin-containing that pain relief in man can be produced by stimulating electrodes implanted in the PAG or in the periventricular region anterior to it (Richardson 1982), in which the hypothalamo-PAG fibres run. This morphine-like pain relief is reversed by naloxone (Hosobuchi et al. 1977 ; Richardson and Akil, 1977).

Within the PAG itself, there are inhibitory interneurones which are inhibited by long inhibitory fibres, which accounts for release of activity in the PAG-NRM pathway and thus inhibition in the spinal cord via the inhibitory NRM-spinal pathway.

Thus the pathway descending from the PAG is responsible for a number of forms of stimulation-produced analgesia:

1. Via the dorsal columns and anterior pretectal nucleus (see above). This explains (i) why analgesia can be obtained when stimulation of the transected dorsal columns above the level of pain ; and (ii) why the literature is ambivalent about the effect of naloxone on TENS and DCS : the GABA-dependent segmental mechanism is not naloxone-reversible because its transmitter (GABA) is not morphine-like but the long loop mechanism through the anterior pretectal nucleus and PAG is dependent on morphine-like transmitters and is therefore naloxone-reversible.

2. Naloxone-reversible heterosegmental acupuncture works through the spinothalamic branches projecting to PAG (Fig. 4 ).

3. Modulation of pain perception through the emotional or paychic state of the individual may depend on the projection from prefrontal cortex via hypothalamus to PAG.

\section{参考文献}

1) Abdel-Maguid TE, Bowsher D; Interneurons and proprioneurons in the adult human spinal grey matter and general somatic afferent cranial nerve nuclei. J Anat 139: 9-20, 1984

2) Beitz $\mathrm{AJ}$ : The sites of origin of brainstem neuratensin and serotonin projections to the rodent nucleus raphe magnus. J Neurosci $2: 829-834,1982$

3) Bjökeland $\mathrm{M}$, Boivie $\mathrm{J}$; An anatomical study of the projections from the dorsal column nuclei to the midbrain in the cat. Anat Embryol 170:29-43, 1984

4) Bloom FE, Battenberg E, Rossier J, et al. : Neurons containing $\beta$-endorphin in rat brain exist separately from those containing enkephalin : Immunocytochemical studies. Proc Natl Acad Sci USA : 75, 1591 - 1595, 1978

5 ) Bowsher D : Role of the reticular formation in response to noxious stimulation. Pain 2 : $361-378,1976$

6 ) Bowsher D, Mallart A, Petit D, et al. : A bulbar relay to centre médian. J Neurophysiol 31 : $288-300,1968$

7) Bowsher D: Termination of the central pain pathway in man : the conscious appreciation of pain. Brain $80: 606-622,1957$

8) Brown AG, Rose PK, Snow PG : Morphology and organization of axon collaterals from afferent fibres of slowly-adapting type I units in cat spinal cord. J Physiol (London) 277 : 
$15-27,1978$

9) Chan SHH : What is being stimulated in acupuncture: Evaluation of the existence of a specific substrate. Neurosci Behav Rev $8: 25$ - 33, 1984

10) Cheng RSS, Pomeranz $\mathrm{BH}$ : Electroacupuncture analgesia is mediated by stereospecific opiate receptors and is reversed by antagonists of Type I receptors. Life Sci $26: 631-638$, 1980

11) Chiang $\mathrm{CY}$, Chang $\mathrm{CT}$, Chu HL, et al.:Peripheral afferent pathway for acupuncture analgesia. Sci Sin 16:210-217, 1973

12) Duggan AW, Foong FW : Bicuculline and spinal inhibition produced by dorsal column stimulation in the cat. Pain $22: 249-259,1985$

13) Glazer EJ, Basbaum AI : Axons which take up $\left[{ }^{3} \mathrm{H}\right]$ serotonin are presynaptic to enkephalin immunoreactive neurons in cat dorsal horn. Brain Res $289: 389-391,1984$

14) Gobel S, Falls WM, Bennet GJ, et al., An E.M. analysis of the synaptic connections of horseradish peroxidase filled stalked cells and islet cells in the substantia gelatinosa of the adult cat spinal cord. J Comp Neurol 194:781-807, 1980

15) Goulden EA : The treatment of sciatica by galvanic acupuncture. Br Med J $1: 523-524$, 1921

16) Hammond DL, Tyle GM, Yaksh TL : Effects of 5-hydroxytryptamine and noradrenaline into spinal cord superfusates during stimulation of the rat medulla. J Physiol (London) $359: 151$ - 162, 1985

17) Harper AA, Lawson $\mathrm{SN}$ : Electrical properties of rat dorsal root ganglion neurones with different peripheral nerve conduction velocities. J Physiol (London) 359;47-63, 1985

18) Heimer L, Wall PD : The dorsal root distribution of to the substantia gelatinosa in the rat, with a note on distribution in the cat. Exp Neurol $6: 89-99,1968$

19) Hosobuchi $Y$, Adams JE, Linchitz $R$ : Pain relief by electrical stimulation of central gray matter in humans and its reversal by naloxone. Science $197: 183-186,1977$

20) Kevetter GA, Haber LH, Yezierski RP, et al. : Cells of origin of the spinoreticular tract in the monkey. J Comp Neurol $207: 61-74,1982$

21) Kumazawa T, Perl ER : Exzcitation of marginal and substantia gelatinosa neurons in the primate spinal cord : indications of their place in dorsal horn functional organization. $J$ Comp Neurol $177: 417-434,1978$

22) Kuru M : Sensory paths in the spinal cord and brain stem of man. Tokyo, Sogensya, 1949

23) Leranth CS, Maxwell DJ, Verhofstad AAJ : Ultrastructure of serotonin-immunoreactive boutons in the substantia gelatinosa of the rat's spinal cord. J-Physiol 355:20, 1984

24) Liu YK, Varela M, Oswald $R$ : The correspondence between some motor points and acupuncture loci. Am J Chin Med $3: 347-358,1977$

25) Lundebarg TCM : Vibratory stimulation for the alleviation of chronic pain. Acta Physiol Scand (Suppl.) 523: 1-51, 1983

26) Mantyh $\mathrm{PW}:$ Forebrain projections to the periaqueductal gray in the monkey, with observations in the cat and rat. J Comp Neurol 206:146-158, 1982

27) Mantyh PW : The ascending input to the midbrain periaqueductal gray of the primate. J Comp Neurol $211: 50-64,1982$

28) Maxwell DJ, Leranth CS, Verhofstad AAJ : Fine structure of serotonin-containing axons 
in the marginal zone of the rat spinal cord. Brain Res $266: 233-260,1983$

29) Mayer DJ, Liebeskind JC : Pain reduction by focal electrical stmulation of the brain : An anatomical and behavioral analysis. Brain Res $68: 73-79,1974$

30) Mayer DJ, Price DD, Rafii A : Antagonism of acupuncture analgesia in man by the narcotic antagonist naloxone. Brain Res $121: 368-372,1977$

31) Melzack R, Wall PD:Pain mechanisms : A new theory. Science 150:: 971-979, 1965

32) Melzack R, Stillwell DM, Fox EJ : Trigger points and acupuncture points for pain: correlations and implications. Pain 3:3-23, 1977

33) Pechura CM, Liu RPC : Spinal neurons which project to the periaqueductal gray and the medullary reticular formation via axon collaterals : A double-label fluorescence study in the rat. Brain Res $374: 357-361,1986$

34) Rees H, Roberts MHT: Activation of cells in the anterior pretectal nucleus by dorsal column stimulation in the rat. J Physiol $417: 361-374,1989$

35) Rees H, Roberts MHT : Antinociceptive effects of dorsal column stimulation in the rat: Involvement of the anterior pretectal nucleus. J Physiol 417:375-388, 1989

36) Rethelyi M, Light AR, Perl ER: Synaptic complexes formed by functionally defined primary afferent units with fine myelinated fibers. J Comp Neurol $207: 381-393,1982$

37) Reynolds DV : Surgery in the rat during electrical analgesia induced by focal brain stimulation. Science $164: 444-445,1969$

38) Richardson DE, Akil $\mathrm{H}$ : Pain reduction by electrical brain stimulation in man. J Neurosurg $47: 178-194,1977$

39) Richardson $\mathrm{DE}$ : Analgesia produced by stimulation of various sites in the human $\beta-$ endorphin system. Appl Neurophysiol 45:116-122, 1982

40) Ruda MA, Coffield J, Dubner R: Demonstration of postsynaptic opioid modulation of thalamic projection neurons by the combined techniques of retrograde horseradish peroxidase and enkephalin immunocytochemistry. J Neurosci $4: 2117-2132,1984$

41) Sjölund BH, Eriksson MBE : The influence of naloxone on analgesia produced by peripheral conditioning stimulation. Brain Res $173: 295-302,1979$

42) Solodkin M, Jimenez I, Rudomin P : Identification of common interneurons mediating preand post-synaptic inhibition in the cat spinal cord. Science $224: 1453-1455,1984$

43) Soper WY, Melzack R : Stimulation-produced analgesia : evidence for somatotopic organization in the midbrain. Brain Res $251: 301-312,1982$

44) Sugiura Y, Lee CL, Perl ER : Central projection of identified, unmyelinated (C) afferent fibers innervating mammalian skin. Science $234: 358-361,1986$

45) Todd AJ, McKenzie J : GABA-immunoreactive neurons in the dorsal horn of the spinal cord. Neurosci $32: 799-806,1989$

46) Tsou K, Jang CS : Studies on the site of analgesic action of morphine by intracerebral microinjection. Sci Sin 13:1099-1109, 1964

47) Wall PD, Sweet WH : Temporary abolition of pain in man. Science 155:108-109, 1967

48) Wang KM, Yao SM, Xian YL, et al. : A study of the receptive field of acupoints and the relationship between characteristics of needling sensation and groups of afferent fibres. Sci Sin 28:963-971, 1985

49) Willis WD, Kenshalo DR, Leonard RB: The cells of origin of the primate spinothalamic 
tract. J Comp Neurol 188:543-574, 1979

50) Nakatani Y : Introduction to Ryodoraku. Acupunct Dig $3: 70-78,1967$

\section{要 旨}

1. 刺激鎮痛法（Stimulation-produced analgesia : SPA）には、2 種類のあのがある。

2. まず電気による経皮的神経刺激 (TENS)。これは高頻度, 低強度の刺激で、太い低閾値有髄一 次求心性神経 $(\mathrm{A} \beta)$ を賊活化する。

3. 次に銊。これは低頻度, 高強度の刺激である。小さな有䯣高閾値一次求心性神経 $(\mathrm{A} \delta$ および第 3 群の神経線維）を賦活化する。

4. 分節性作用の TENS は GABA 作働性の抑制性介在ニューロンを介して作用するため、ナロキ ソン可逆性はない。

5. 分節性の鍼はエンケファリン作働性の㧕制性介在ニューロンを介して作用するため、ナロキン ン可逆性である。

6. どちらの夕イプの SPA あ長い回路を通って異分節的にあはたらく。

7. TENS および脊䯣後索刺激（DCS）の場合、インパルスは脊髄後索および内側毛帯を通って上 行し、中脸の水道管周囲灰白質 (PAG) に突起を出す視蓋前前核に達する。

8、また, ピン刺し刺激（鍼）の場合，メッセージは, PAGに達する副軸索に枝を出している脊䯣 視床路を通って上行する。

9. PAG は、延䯣の大繾線核 (NRM) を通って脊髄に（白背側索を通って）オピエート作働性の下 行性突起を出しているが、そこでは侵害性刺激メッセージ伝達が、長い上行路へ伝わるのを抑 制する。

10，従って、異分節機構は、銊および TENS の両方とも、ナロキソン可逆性である。

11. PAG、または視床下部からPAGに至る下行性抑制系のいずれかにおける植え込み電極による SPA あまた、ナロキソン可逆性である。

Fig. 2

Fig. 1

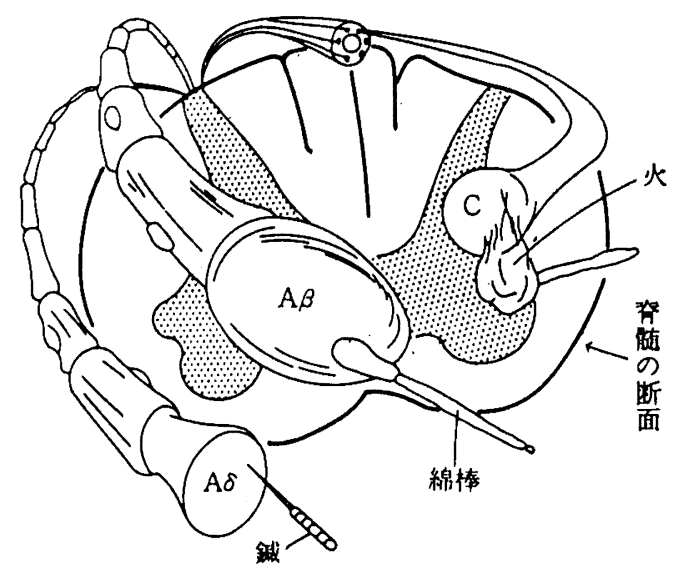

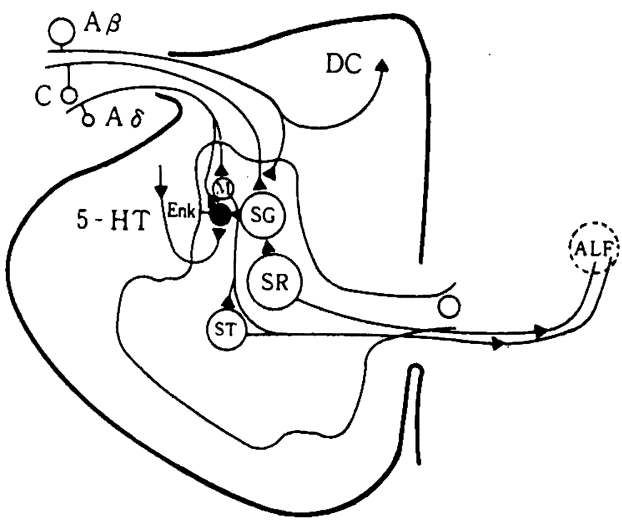

The Dorsal Higrn-This gnphic demonstratas the components of the doral born. As peripheral sfifereats from pinprick rocepton end on the merginal zove (M) cells in lamina f

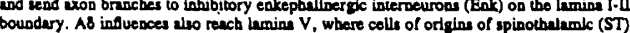
coundary. As instuences ateo reach hamina V, where cells of origins of spinothalamic (ST) enterolnternl funiculus (NLF) toward the ventrobasal thaliamus. Polymodul pociceptor reach the spisal cord in primery efferent C fbern (C). Their SP.trinamiting aona end in

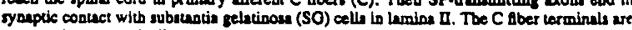
contacted presynaptically by collateral branches of largo low-threshold eutapoous atoreats (AB), whose mein brasches ascend into the ipelintenal doral columns (DC). The SO cells also are inhibited by the Enk interoeurons on the lamion I-I border, in a aloxone-roversible

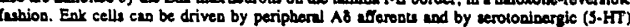
abers descesding into the dornoluteral white funjeculus of the spinal cord. SO neuron indiroctly activate cells of origin of spinoreticular (SR) exona in luminee VII and VIR. SR

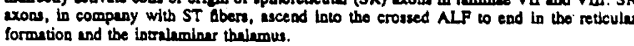


Fig. 3

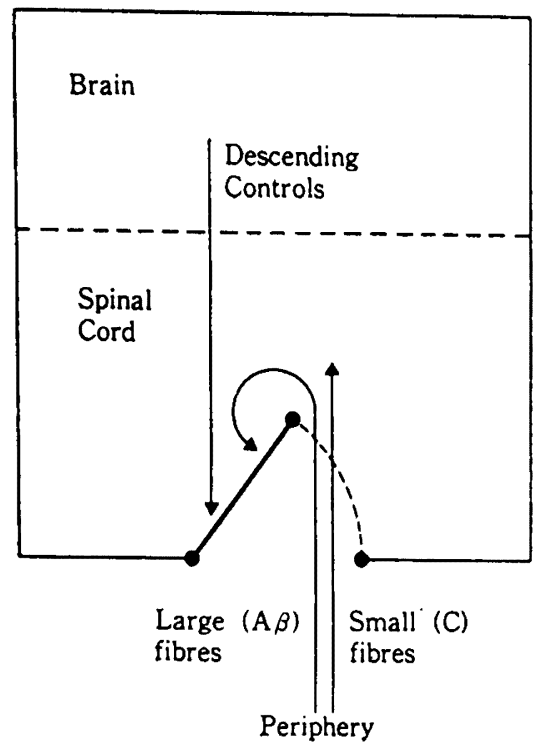

Gate control.

A its simplest, the gate control theory postulates that impulses trom small (pain) peripheral nerve fibres push coen a gate, or door, and enter the centraf nervous system. The stronger the pain, the crealer the force opening the gate. system. The stronger the pain, the grealer the force opening the gate.
Opposing this are two forces tending 10 close the gate. The first comes from outside (i.e. The perlohery) and consists of large cutaneous sensory fiores. activaled, lor example, by the process of "robing hibether. Tho second consist molvetion, control systoms deaconding irom the braln and aclivelod by molivation, such that, for example, al the time of rescuing a baby from a burning
house, one is unaware of the pain.

Fig. 5

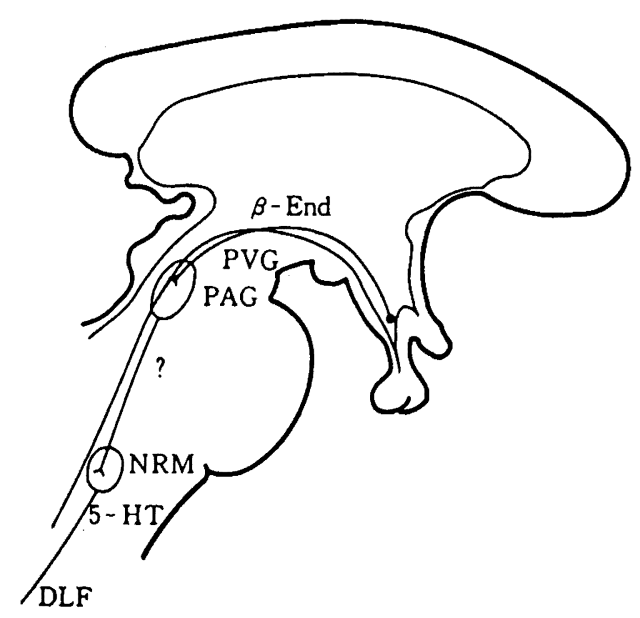

Descending Control Syrtems-Cells in the infuodibular region (DNP) of the hypochalamus givo rise to B-eodorphio-contuining axons ( $\beta-E N D)$, which pass through the periventriculer gray (PVO) region to the wall of the third ventricle and end in the

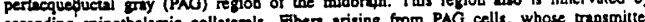

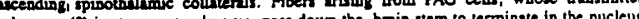

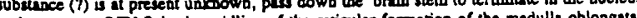
mpbe magnus (NRM) in the midline of the reticular forrasion of the medull oblongats. NRM axons, whose trasminter substence is serolodin (S-H). descend through the dorsolateral funiculus (DLF) of the spinal white mather the spinal gray.
Fig. 4

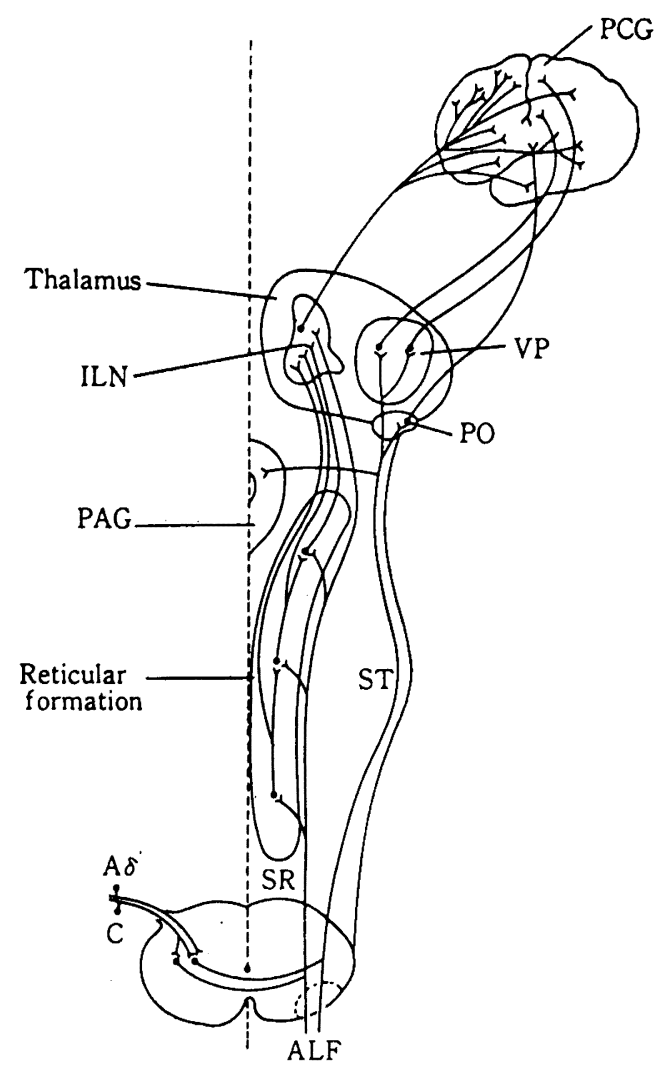

Central Paln Pathway - The anterolateral funiculur (ALP) of the spinel whits matter (p) binds of long ascending fibers: spinothalemic (ST) exons, principally activnted by AB (pisprick) peripberd affereats, and spiporeticuler (SR) wons, activeted matnly, but demige) peripbenl afereats. Abovo the spinal card, ST fiben remain on the latend border of the brain stem and, after geving off collaternds to the 政 vestrobesel thelemes bes two parts: the veotroposterior nuclous (NP), which projects poist-to-point to the firs romitic rensory are in the postecatral gyrus (PCO), and be posterior group (PO), of calls, which project to the wecond comntx enenory tres in the

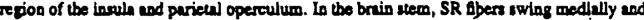
ead at various levels of the reticular formution; the loagest SR aroos reach the intrilemine auclei (ILN) of the thilumes. The redicular formation aleo projocts to the I.N, which gives rise to the so-alled "diffise" thalemocortical projoction. This projoction reaches all areas of the sonprimery cortex, although with pretronul predominasce. 